\title{
Chemoimmunotherapy in Advanced Renal Cell Carcinoma: A Case Report of a Long-Term Survivor Adjunctly Treated with Viscum album Extracts
}

\author{
Paul G. Werthmann ${ }^{a, c}$ Lothar Kindermann ${ }^{b}$ Gunver S. Kienle ${ }^{\text {a, } c}$ \\ ${ }^{a}$ Institute for Applied Epistemology and Medical Methodology at the University of Witten/Herdecke, Freiburg im \\ Breisgau, Germany; ${ }^{b}$ Community Practice for General Medicine, Wennigsen, Germany; ${ }^{c}$ Center for Complementary \\ Medicine, Institute for Infection Prevention and Hospital Epidemiology, Medical Center - University of Freiburg, \\ Faculty of Medicine, University of Freiburg, Freiburg im Breisgau, Germany
}

Keywords

Renal clear cell carcinoma $\cdot$ Interleukin-2 $\cdot$ Interferon-a2a

13-cis-Retinoic acid · Viscum album

\begin{abstract}
Introduction: Metastatic renal cell carcinoma has a poor prognosis. Treatment approaches with immunotherapy show promising results in subpopulations. Viscum album extracts used as an adjunct to cancer treatment - have cytotoxic, apoptogenic, and immune-stimulating properties and show synergistic effects with chemotherapy agents. Case Report: A 51-year-old man was diagnosed with metastatic renal cell carcinoma of clear cell histology which was classified as pT3a, N1, M1, G3. Nephrectomy was performed, and the patient received chemoimmunotherapy (interferon-a2a, interleukin-2, fluorouracil, isotretinoin). Additionally, he received V. album extracts as intravenous infusions and subcutaneous injections. One year after surgery, the patient was in complete remission, which is ongoing 18 years after the initial diagnosis. Discussion: This case shows an extraordinarily long survival of a metastasized renal cell carcinoma patient under chemoimmunotherapy and fever-inducing V. album extracts. This combined treatment might have synergistically contributed to tumor remission and control. With regard to clinical relevance, further investigations are needed. @ 2019 The Author(s)
\end{abstract}

Published by S. Karger AG, Basel

\section{Schlüsselwörter}

Klarzelliges Nierenzellkarzinom • Interleukin-2 . Interferon-a2a · 13-cis-Retinsäure · Viscum album

\section{Zusammenfassung}

Hintergrund: Das metastasierte klarzellige Nierenzellkarzinom hat eine schlechte Prognose. Behandlungsansätze mit Immuntherapien zeigen positive Ergebnisse in Subpopulationen. Viscum-album-Extrakte - als Begleitbehandlung in der Krebstherapie - haben zytotoxische, apoptosefördernde und immunstimulierende Eigenschaften und zeigen synergistische Effekte mit Chemotherapeutika. Fallbericht: Bei einem 51-jährigen Mann wurde ein metastasiertes klarzelliges Nierenzellkarzinom diagnostiziert, das als pT3a, N1, M1, G3 klassifiziert wurde. Es wurde eine Nephrektomie durchgeführt, und der Patient erhielt eine Immunochemotherapie (Interferona2a, Interleukin-2, Fluorouracil, Isotretinoin). Begleitend erhielt er intravenöse Infusionen und subkutane Injektionen mit V.-album-Extrakten. Ein Jahr nach der Operation war der Patient in einer vollständigen Remission, die nun bereits 18 Jahre seit der Erstdiagnose anhält. Diskussion: Dieser Fallbericht zeigt ein besonders langes Überleben eines Patienten mit metastasiertem Nierenzellkarzinom unter Immunochemotherapie und fieberin- 
duzierenden V.-album-Extrakten. Diese kombinierte Behandlung hat möglicherweise synergistisch zur Tumorremission und Tumorkontrolle beigetragen. Hinsichtlich der klinischen Relevanz sollten weitere Untersuchungen erfolgen.

(c) 2019 The Author(s)

Published by S. Karger AG, Basel

\section{Introduction}

Cancer of the kidney has a high and rising incidence (12.1/100,000 in Europe [1]) with a male predominance of approximately $2: 1$. Risk factors are smoking, obesity, and hypertension [2]. Survival rates of kidney cancer have improved - especially due to early detection, refined surgical techniques, and new therapeutic agents [3].

Renal cell carcinoma (RCC) accounts for $90 \%$ of all kidney cancers, and clear cell carcinoma (ccRCC) is its most common histological subtype (approx. 75\%). Recommended treatment is surgical excision/cytoreduction in all stages. Immunotherapy and targeted therapies are used in advanced stages of the disease [4]. Histologically, ccRCC shows extraordinarily high infiltration rates with T cells [5]; ccRCC shows a very high number of insertionand-deletion mutations, when compared to other cancer types [6], and spontaneous remission of lung metastases has been occasionally reported $[7,8]$. These properties make this tumor highly immunogenic.

Different species of Viscum album have been used in traditional medicines and have been widely investigated scientifically in the last few decades [9]. V. album extracts (VAE) - aqueous extracts from European mistletoe ( $V$ is cum album L.) - show a variety of antineoplastic properties: cytotoxic and proapoptotic effects, immune stimulation, downregulation of cancer genes (e.g., transforming growth factor $\beta$ and matrix metalloproteinases), reduction of cell migration, and interference with tumor angiogenesis [9-12]. Pharmacologically active compounds include mistletoe lectins, viscotoxins, oligo- and polysaccharides, flavonoids, and triterpene acids [9]. Different commercial VAE preparations for injection (usually subcutaneously but also intralesionally or intravenously) are used as a supportive therapy in patients with cancer [13]. VAE are safe, even when used in higher dosages; they have dose-dependent, self-limited side effects such as erythema at the injection site, fever, flu-like symptoms, and rare pseudoallergic reactions $[14,15]$. In a trial by Brinkman and Hertle [16], treatment with VAE was compared with immunotherapy in advanced RCC and showed fewer responses to therapy and fewer side effects. Tumor remission has been repeatedly described, usually under high-dose VAE treatment [17], and prolonged survival was seen in a trial of advanced pancreatic cancer patients [18].

\section{Case Report}

A 51-year-old wholesaler presented with chronic cough that he had experienced for 5 months. He had no additional symptoms, no hypertension, and a normal body weight; he had stopped smoking 12 years previously. He was diagnosed with metastatic RCC, and nephrectomy with metastasectomy (of the epicardial metastasis) was performed; due to low hemoglobin, after surgery 2 red cell concentrates had to be given. The primary tumor had a size of 110 $\times 90 \times 95 \mathrm{~mm}$. Histological investigations showed mainly clear cell carcinoma cells; however, spindle cell and granular cell regions were present. Radiological investigation showed pulmonary metastases, and the tumor was classified as pT3a, N1, M1, G3.

The patient was enrolled in a clinical trial investigating the efficacy and safety of chemoimmunotherapy, and he received $3 \mathrm{cy}-$ cles of subcutaneous interferon- $\alpha 2 a$ (IF- $\alpha 2 a)$, interleukin-2 (IL-2), intravenous fluorouracil (5-FU) and oral isotretinoin [19]. The regimen was IF- $\alpha 2 \mathrm{a}\left(5 \times 10^{6} \mathrm{IU} / \mathrm{m}^{2}\right.$, day 1 , weeks $1+4$; days 1,3 , 5 , weeks $2-3 ; 10 \times 10^{6} \mathrm{IU} / \mathrm{m}^{2}$, days 1,3 , 5, weeks $\left.5-8\right)$, IL-2 (10 $\times$ $10^{6} \mathrm{IU} \mathrm{m}^{2}$, twice daily, days $3-5$, weeks $1+4 ; 5 \times 10^{6} \mathrm{IU} / \mathrm{m}^{2}$, days $1,3,5$, weeks $2+3)$, and isotretinoin (20 mg thrice daily) over 8 weeks. He experienced nausea, vomiting, and weight loss of $12 \mathrm{~kg}$ during the treatment period.

The patient asked his general practitioner, who had special training in integrative medicine, for additional treatment and received VAE as intravenous infusions and subcutaneous injections in addition to the chemoimmunotherapy. This treatment was chosen to increase the quality of life and to contribute to tumor control. VAE infusions were administered bi-weekly, and subcutaneous VAE were injected twice weekly but not on days of chemoimmunotherapeutic treatment. After intravenous VAE treatment, the patient experienced a fever slightly above $38^{\circ} \mathrm{C}$, which resolved after 1.5 days. The subcutaneous injection sites showed signs of slight induration and inflammation, which were self-limited.

After 7 months of therapy, a partial response of the lung metastases was seen in computed tomography scan; 1 year after surgery, the patient was in complete remission of all tumor lesions, which remained stable until the publication of this report - 18 years after initial diagnosis - under continued subcutaneous VAE treatment (Fig. 1). The patient is currently enjoying good quality of life, has a body weight of $145 \mathrm{~kg}$ (size $176 \mathrm{~cm}$ ), and takes amlodipine and losartan for hypertension.

\section{Discussion}

We report a case of extraordinarily long cancer-free survival of a patient with ccRCC stage IV. He underwent nephrectomy, metastasectomy (epicardial), chemoimmunotherapy, and VAE therapy. Under this treatment, the patient showed complete resolution of his lung metastases within 1 year, and he has remained disease-free for 17 years (18 years from initial diagnosis).

Long-time survival ( $>5$ and $>10$ years) of metastatic RCC patients who showed complete remission under treatment combinations including high-dose IL-2 have previously been described [20-23], but late relapses after more than 10 years have also been reported [20]. The rationale for using IL-2-based immunotherapies in immunogenic cancer is the induction of proliferation of T-cell clones against the tumor tissue [24]. Relapse after therapy 


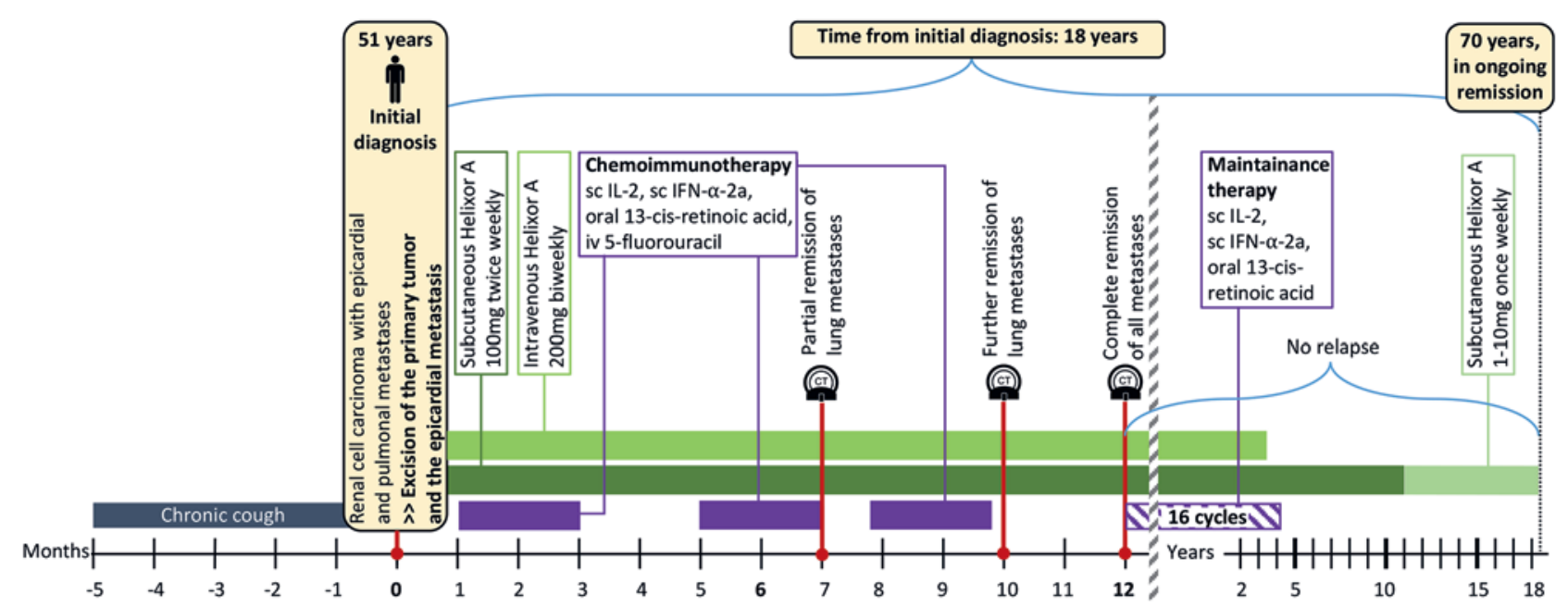

Abbreviations: sc: subcutaneous; IL-2: Interleukin-2; IFN- $\alpha$-2a: Interferon- $\alpha$-2a; iv: intravenous; Helixor A: Viscum album extract from the host tree fir.

Fig. 1. Timeline of the patient with metastatic renal clear cell carcinoma.

can be interpreted as depletion of the respective T-cell clones.

VAE acts as an immune stimulant of pathways of the innate and adaptive immune system [9]. Subpopulations of $\mathrm{T}$ cells show proliferation after application of VAE. Hence, VAE may have contributed to a stronger proliferation induction of T-cell clones against the tumor tissue in the case presented here. Long-time treatment with VAE may have contributed to tumor control in stimulating further proliferation of the respective $\mathrm{T}$-cell clones [9].

As this is the first report of a patient treated with a combination of IL-2-based immune therapy with VAE, it is important to note that the combination was well tolerated and did not lead to any severe side effects or immune system deterioration. However, our findings represent a singular case, and such a treatment cannot be recommended as standard treatment before more data are available. Similar observations of treatment safety are reported for combination therapy with immune checkpoint inhibitors with VAE [25].

The individual impact of the single agents used in this case cannot be conclusively determined; furthermore, even spontaneous remission of lung metastases after nephrectomy with long cancer-free survivals has been reported [7]. However, given the clinically relevant positive outcome of this case, further investigation should follow. The combined treatment of patients with VAE and IL-2based immunotherapies as well as the use of VAE in RCC should be carefully documented and published to determine the directions of future research.

\section{Acknowledgments}

We are thankful to the "Stiftung Integrative Medizin" for financial support. This case report was prepared following the CARE Guidelines [26].

\section{Statement of Ethics}

Informed consent was received from the patient for the publication of the report and accompanying images. The patient read the submission version of the report and confirmed its content.

\section{Disclosure Statement}

The authors declare no conflict of interest.

\section{Author Contributions}

P.G.W., L.K., and G.S.K. contributed to the case report design. L.K. was the physician in charge who provided the patient's information. P.G.W. and L.K. collected and provided the data. P.G.W. was the principal author of the paper, had full access to all data, and is the guarantor. G.S.K. supervised the report and the publication process. 


\section{References}

1 Ferlay J, Steliarova-Foucher E, Lortet-Tieulent J, Rosso S, Coebergh JW, Comber H, et al. Cancer incidence and mortality patterns in Europe: estimates for 40 countries in 2012 Eur J Cancer. 2013 Apr;49(6):1374-403.

2 Hsieh JJ, Purdue MP, Signoretti S, Swanton C Albiges L, Schmidinger M, et al. Renal cell carcinoma. Nat Rev Dis Primers. 2017 Mar;3: 17009.

3 Pantuck AJ, Zisman A, Belldegrun AS. The changing natural history of renal cell carcinoma. J Urol 2001;166:1611-23.

4 Rini BI, McDermott DF, Hammers H, Bro W, Bukowski RM, Faba B, et al. Society for Immunotherapy of Cancer consensus statement on immunotherapy for the treatment of renal cell carcinoma. J Immunother Cancer. 2016 Nov;4(1):81.

5 Senbabaoğlu Y, Gejman RS, Winer AG, Liu M, Van Allen EM, de Velasco G, et al. Tumor immune microenvironment characterization in clear cell renal cell carcinoma identifies prognostic and immunotherapeutically relevant messenger RNA signatures. Genome Biol. 2016 Nov; 17(1):231.

6 Turajlic S, Litchfield K, Xu H, Rosenthal R, McGranahan N, Reading JL, et al. Insertionand-deletion-derived tumour-specific neoantigens and the immunogenic phenotype: a pan-cancer analysis. Lancet Oncol 2017. Available from: http://www.sciencedirect. com/science/article/pii/S1470204517305168 https://doi.org/10.1016/S 1470 2045(17)30516-8

7 Vogelzang NJ, Priest ER, Borden L. Spontaneous regression of histologically proved pulmonary metastases from renal cell carcinoma: a case with 5-year followup. J Urol. 1992 Oct; 148(4):1247-8.

8 Gleave ME, Elhilali M, Fradet Y, Davis I, Venner P, Saad F, et al. Interferon gamma-1b compared with placebo in metastatic renalcell carcinoma. N Engl J Med 1998;338:126571.

9 Singh BN, Saha C, Galun D, Upreti DK, Bayry J, Kaveri SV. European Viscum album: a potent phytotherapeutic agent with multifarious phytochemicals, pharmacological properties and clinical evidence. RSC Advances. 2016; 6(28):23837-57.

10 Podlech O, Harter PN, Mittelbronn M, Pöschel S, Naumann U. Fermented mistletoe extract as a multimodal antitumoral agent in gliomas. Evid Based Complement Alternat Med. 2012;2012:501796.

11 Elluru SR, Duong Van Huyen JP, Delignat S, Prost F, Heudes D, Kazatchkine MD, et al. Antiangiogenic properties of viscum album extracts are associated with endothelial cytotoxicity. Anticancer Res. 2009 Aug;29(8): 2945-50.

12 Steinborn C, Klemd AM, Sanchez-Campillo AS, Rieger S, Scheffen M, Sauer B, et al. Viscum album neutralizes tumor-induced immunosuppression in a human in vitro cell model. PLoS One. 2017 Jul;12(7):e0181553.

13 Kienle GS, Kiene H. Complementary cancer therapy: a systematic review of prospective clinical trials on anthroposophic mistletoe extracts. Eur J Med Res. 2007 Mar;12(3):103-19.

14 Kienle GS, Grugel R, Kiene H. Safety of higher dosages of Viscum album L. in animals and humans-systematic review of immune changes and safety parameters. BMC Complement Altern Med. 2011 Aug;11(1):72.
15 Steele ML, Axtner J, Happe A, Kröz M, Matthes $\mathrm{H}$, Schad F. Adverse drug reactions and expected effects to therapy with subcutaneous mistletoe extracts (Viscum album L.) in cancer patients. Evid Based Complement Alternat Med. 2014;2014:724258.

16 Brinkmann OA, Hertle L. Kombinierte Zytokintherapie vs. Misteltherapie bei metastasiertem Nierenzellkarzinom: Klinischer Vergleich des Therapieerfolgs einer kombinierten Gabe von Interferon alfa-2b, Interleukin-2 und 5-Fluorouracil gegenüber einer Behandlung mit Mistellektin. Onkologe. 2004;10(9): 978-85.

17 Mabed M, El-Helw L, Shamaa S. Phase II study of viscum fraxini-2 in patients with advanced hepatocellular carcinoma. Br J Cancer. 2004 Jan;90(1):65-9.

18 Tröger W, Galun D, Reif M, Schumann A, Stanković N, Milićević M. Viscum album [L.] extract therapy in patients with locally advanced or metastatic pancreatic cancer: a randomised clinical trial on overall survival. Eur J Cancer. 2013 Dec;49(18):3788-97.

19 Atzpodien J, Kirchner H, Rebmann U, Soder $\mathrm{M}$, Gertenbach U, Siebels M, et al. Interleukin-2/interferon-a2a/13-retinoic acid-based chemoimmunotherapy in advanced renal cell carcinoma: results of a prospectively randomised trial of the German Cooperative Renal Carcinoma Chemoimmunotherapy Group (DGCIN). Br J Cancer. 2006 Aug; 95(4):463-9.

20 Klapper JA, Downey SG, Smith FO, Yang JC, Hughes MS, Kammula US, et al. High-dose interleukin-2 for the treatment of metastatic renal cell carcinoma : a retrospective analysis of response and survival in patients treated in the surgery branch at the National Cancer Institute between 1986 and 2006. Cancer. 2008 Jul;113(2):293-301.

21 Fisher RI, Rosenberg SA, Fyfe G. Long-term survival update for high-dose recombinant interleukin-2 in patients with renal cell carcinoma. Cancer J Sci Am. 2000 Feb;6 Suppl 1:S55-7.

22 Belldegrun AS, Klatte T, Shuch B, LaRochelle JC, Miller DC, Said JW, et al. Cancer-specific survival outcomes among patients treated during the cytokine era of kidney cancer (1989-2005): a benchmark for emerging targeted cancer therapies. Cancer. 2008 Nov; 113(9):2457-63.

23 Rosenberg SA, Yang JC, White DE, Steinberg SM. Durability of complete responses in patients with metastatic cancer treated with high-dose interleukin-2: identification of the antigens mediating response. Ann Surg 1998; 228:307.

24 Liao W, Lin JX, Leonard WJ. IL-2 family cytokines: new insights into the complex roles of IL-2 as a broad regulator of T helper cell differentiation. Curr Opin Immunol. 2011 Oct;23(5):598-604.

25 Thronicke A, Steele ML, Grah C, Matthes B, Schad F. Clinical safety of combined therapy of immune checkpoint inhibitors and Viscum album L. therapy in patients with advanced or metastatic cancer. BMC Complement Altern Med. 2017 Dec;17(1):534.

26 Riley DS, Barber MS, Kienle GS, Aronson J, von Schoen-Angerer T, Tugwell $\mathrm{P}$, et al. CARE guidelines for case reports: explanations and elaboration document. J Clin Epidemiol. 2017 Sep;89:218-35. 